Dewi, S.M. • Y. Yuwariah · W.A. Qosim · D. Ruswandi

\title{
Pengaruh cekaman kekeringan terhadap hasil dan sensitivitas tiga genotip jawawut
}

\section{Effect of water stress on yield and sensitivity of three genotypes of millet (Setaria italica L. Beauv)}

Diterima : 14 Desember 2018/Disetujui : 18 Desember 2019 / Dipublikasikan : 31 Desember 2019

CDepartment of Crop Science, Padjadjaran University

\begin{abstract}
Millet is one of Indonesian local food crops that can develope as food sources. The purpose of this study was to obtain the genotypes of millet which gave the best effect on the yield and lower sensitive at various levels of water supply in the plastic house. The study was conducted from June to September 2017 at the Experimental Station of The Faculty of Agriculture, Padjadjaran University, Sumedang, Indonesia. The research used Split Plot Design with three levels of main plot: genotypes 44,46 , and 48. Subplot consisted of three levels of water field capacity: $75 \%, 50 \%$ and $25 \%$. The results showed that the genotype 46 and 48 had the higher seed weight than genotype $44\left(32,50 \mathrm{~g}^{-1}\right.$ and $32,57 \mathrm{~g}^{-1}$ vs $25,81 \mathrm{~g}^{-1}$ ), but the genotype 48 had sensitive(S) with sensitivity index 1,25. Genotype 44 and 46 had medium toleran (MT) with sensitivity index 0,87 and 0,85 . Even had the lower yield, genotype 44 had adaptive potential to developed in the dry land, with proline production more than other genotypes at the three levels of different available water capacity, and yield response curve was still linier when linked between proline, yield and sensitivity index.
\end{abstract}

Keywords: Millet genotype - Soil water content • Sensitivity

Sari. Jawawut merupakan salah satu tanaman serealia lokal Indonesia yang dapat dikembangkan dan dimanfaatkan sebagai sumber pangan. Tujuan dari penelitian ini adalah untuk mendapatkan genotip jawawut yang memberikan hasil paling

\footnotetext{
Dikomunikasikan oleh Aep Wawan Irwan dan Agus Wahyudin

Dewi, S.M. · Y. Yuwariah · W.A. Qosim · D. Ruswandi Departemen Budidaya Pertanian, Fakultas Pertanian, Universitas Padjadjaran

Jl, Raya Bandung Sumedang KM. 21, Sumedang 45363

Korespondensi : yuyun.yuwariah@unpad.ac.id
}

baik dan sensitivitas paling rendah pada berbagai tingkat pemberian air di rumah plastik. Penelitian dilaksanakan pada bulan Juni sampai dengan bulan September 2017 di kebun percobaan Fakultas Pertanian UNPAD. Penelitian ini menggunakan Rancangan Petak Terbagi (Split Plot Design) dengan 3 ulangan. Petak utama terdiri dari tiga macam genotip, yaitu genotip 44, 46, dan 48 . Anak petak terdiri dari tiga taraf kadar air tanah, yaitu $75 \%$, 50\%, dan 25\% dari kapasitas lapang. Hasil penelitian menunjukkan genotip 46 dan 48 menghasilkan bobot biji per rumpun lebih banyak dibandingkan genotip 44, masing-masing sebesar $32,50 \mathrm{~g}^{-1}$ dan $32,57 \mathrm{~g}^{-1}$ vs $25,81 \mathrm{~g}^{-1}$, namun genotip 48 merupakan genotip dengan kriteria peka (P), yang memiliki indeks sensitivitas 1,25. Genotip 44 dan 46 termasuk keriteria medium toleran (MT), dengan indeks sensitivitas masing-masing sebesar 0,87 dan 0,85 . Sekalipun hasilnya paling rendah namun genotip 44 memiliki potensi adaptif untuk dikembangkan di lahan kering dengan kemampuan menghasilkan prolin yang lebih banyak dibandingkan genotip 46 dan 48 pada tiga level pemberian air yang berbeda dengan kurva respons hasil yang masih linier bila dikaitkan antara prolin, hasil, dan indeks sensitivitas.

Kata kunci : Genotip jawawut - Kadar air tanah • Hasil · Sensitivitas.

\section{Pendahuluan}

Bertambahnya jumlah penduduk Indonesia dari waktu ke waktu cukup tinggi, dengan laju kecepatan 1,49\% per tahun. Hal ini menimbulkan permasalahan dalam pengadaan pangan penduduk. Pada tahun 2016, jumlah penduduk Indonesia sebanyak 258.705.000 (Badan Pusat Statistik, 2016). Untuk menghindari terjadinya krisis pangan, perlu dicari berbagai usaha, antara 
lain melalui diversifikasi pangan yang bertujuan untuk menyediakan pangan melalui pemanfaatan pangan lokal, sehingga dapat mengurangi konsumsi beras dan pangan impor. Jawawut merupakan salah satu jenis tanaman biji-bijian yang belum dikenal oleh masyarakat Indonesia, tetapi di beberapa negara seperti Cina, India, dan beberapa negara bagian Eropa Selatan, jawawut telah lama dibudidayakan dan dimanfaatkan dalam berbagai bentuk olahan. Dibandingkan dengan beras, jawawut memiliki beberapa keunggulan, yakni memiliki nilai gizi yang cukup tinggi (karbohidrat, lemak, protein), tahan kekeringan, mempunyai daya adaptasi cukup tinggi terhadap lahan sub-optimal, mudah dibudidayakan dengan hasil yang cukup tinggi yaitu 800-900 kg ha-1 (Miswarti et al., 2014), juga mempunyai ragam kegunaan yaitu sebagai pangan dan pakan (Rauf dan Lestari, 2009). Dari berbagai kelebihan tanaman jawawut di atas, permasalahan yang sering terjadi pada pengembangan tanaman jawawut antara lain adalah terbatasnya varietas unggul yang memiliki ketahanan terhadap cekaman biotik dan cekaman abiotik antara lain kekeringan. Pengujian beberapa genotip jawawut terhadap kekeringan dan relevansinya yang berujung pada hasil dan sensitivitas, penting dilakukan untuk pengembangan kultivar toleran kekeringan.

Kekeringan merupakan istilah untuk menyatakan bahwa tanaman mengalami kekurangan air akibat keterbatasan air dari lingkungan atau media tanam. Widiatmoko et al. (2012) menyatakan bahwa kekeringan disebabkan karena (1) kekurangan suplai air di daerah sistem perakaran dan (2) permintaan air yang berlebihan oleh daun karena laju transpirasi lebih tinggi dibandingkan dengan laju absorpsi air oleh akar meskipun keadaan air tanah tersedia cukup. Apabila jumlah air terbatas, maka air harus dimanfaatkan secara efisien. Air tersedia ditentukan berdasarkan nilai kandungan air (\%) pada keadaan kapasitas lapang (KL; pF 2,54) dan nilai kandungan air (\%) pada keadaan titik layu permanen ( $\mathrm{pF} 4,2$ ). Pemberian air yang berbeda akan menimbulkan respons tanaman yang berbeda pula.

\section{Bahan dan Metode}

Percobaan dilaksanakan di kebun percobaan Fakultas Pertanian Universitas Padjadjaran. Tanaman jawawut ditanam di dalam pot yang dinaungi rumah plastik, pada bulan Juni September 2017. Suhu rata-rata di rumah plastik selama percobaan adalah $24,05^{\circ} \mathrm{C}$ dan kelembaban relatif rata-rata $82,41 \%$.

Bahan-bahan yang digunakan adalah tiga genotip jawawut yaitu genotip 44, genotip 46, genotip 48; pupuk kandang 20 ton ha-1; Urea 100 $\mathrm{kg} \mathrm{ha}^{-1}$ diberikan dua kali saat tanam dan 28 hari setelah tanam (HST) dengan dosis masingmasing setengahnya; SP36 $\left(36 \% \mathrm{P}_{2} \mathrm{O}_{5}\right) 100 \mathrm{~kg}$ ha1 dan $\mathrm{KCl}\left(60 \% \mathrm{~K}_{2} \mathrm{O}\right) 100 \mathrm{~kg} \mathrm{ha}^{-1}$ yang diberikan sekaligus saat tanam.

Penelitian ini menggunakan Rancangan Petak Terbagi (Split Plot Design) dengan petak utama genotip jawawut $(\mathrm{G})$ dan anak petak kadar air tanah (K). Faktor genotip jawawut terdiri dari tiga macam, yaitu: $\mathrm{g}_{1}$ (genotip 44) dengan daya kecambah 88\%; g2 (genotip 46) dengan daya kecambah 92\%; dan $g_{3}$ (genotip 48) dengan daya kecambah 90\%. Genotip 44 berasal dari Biak Numfor Papua, sedangkan genotip 46 dan 48 berasal dari Kabupaten Garut Jawa Barat. Faktor kadar air tanah terdiri dari tiga taraf, yaitu : $\mathrm{k}_{1}$ (75\% KL); $\mathrm{k}_{2}(50 \% \mathrm{KL})$; dan $\mathrm{k}_{3}(25 \% \mathrm{KL})$. Terdapat 9 kombinasi perlakuan dan semua kombinasi perlakuan tersebut masing-masing diulang 3 kali. Benih ditanam di persemaian selama 28 hari, kemudian ditanam di dalam pot di rumah plastik. Pengamatan fase vegetatif dimulai saat umur 29 HST sampai dengan 43 HST, sedangkan pengamatan fase generatif dimulai pada umur 44 HST sampai panen.

Pengamatan komponen hasil meliputi bobot malai, bobot biji per rumpun, dan bobot 1000 butir. Indeks sensitivitas menggunakan rumus dari Utami dan Haryadi; 2016 sebagai berikut :

$$
S=\frac{1-\left(\frac{Y}{Y p}\right)}{1-\left(\frac{X}{X p}\right)}
$$

$S \quad=$ Indeks sensitivitas cekaman kekeringan

$\mathrm{Y}$ = Rata-rata suatu genotip yang mendapat cekaman kekeringan

$\mathrm{Yp}=$ Rata-rata nilai peubah suatu genotip yang tidak mendapat cekaman kekeringan

$\mathrm{X}=$ Rata-rata dari seluruh genotip yang mendapat cekaman kekeringan

$\mathrm{Xp}=$ Rata-rata dari seluruh genotip yang tidak mendapat cekaman kekeringan

Kondisi tercekam dalam penelitian ini ditunjukkan oleh respons genotip pada $25 \% \mathrm{KL}$, sedangkan kondisi optimal ditunjukkan oleh respons genotip pada $75 \% \mathrm{KL}$. 
Perhitungan untuk indeks sensitivitas antara lain meliputi pengamatan tinggi tanaman, jumlah anakan per rumpun, indeks luas daun (ILD), nisbah pupus akar (NPA), panjang malai, bobot malai, indeks kandungan klorofil daun (menggunakan chlorophyll meter SPAD (merk CCM : 200 plus), dilakukan saat akhir fase vegetatif 49 HST pada tiga daun teratas dari tanaman sampel), dan konduktan stomata (mmol $\mathrm{m}^{-2} \mathrm{~s}^{-1}$ menggunakan Leaf Porometer model Sc-1, dilakukan saat umur 60 HST).

Pengamatan penunjang antara lain kandungan air tanah (\%) pada fase vegetatif, pembungaan, dan pengisian biji. Pengukuran kandungan air tanah atas dasar $\mathrm{pF}$ dilakukan di Laboratorium Fisika Tanah IPB dengan menggunakan alat Pressure Plate Extractor dengan tekanan 1/3 atm untuk $\mathrm{pF}$ 4,2. Selain itu juga diamati kandungan prolin ( $\mathrm{mmol} \mathrm{g}^{-1}$ bobot basah) saat panen menggunakan alat Spektrofotometer visible $U V$ pada Panjang gelombang $520 \mathrm{~nm}$.

Kandungan Air Relatif Daun (KARD), ditetapkan dengan mengunakan rumus menurut Arifai (2009) sebagai berikut :

$$
\text { KARD }=\frac{\text { Bobot segar-bobot kering }}{\text { Bobot turgid-bobot kering }}
$$

Pengukuran KARD dilakukan sebelum penyiraman dengan menimbang bobot segar daun. Daun segera direndam dalam air selama 48 jam untuk mendapatkan bobot turgid, kemudian daun ditimbang dan dikeringkan, sehingga mendapatkan bobot kering oven.

Data dianalisis dengan uji $\mathrm{F}$ pada taraf nyata 5\%. Perbedaan di antara perlakuan dianalisis menggunakan uji lanjut dengan uji jarak berganda Duncan pada taraf 5\%.

\section{Hasil dan Pembahasan}

Pada Tabel 1 ditunjukkan bahwa untuk ketiga genotip $g_{1}, g_{2}$, dan $g_{3}$ dengan pemberian air 75, 50, dan 25\% KL semua kandungan air tanah (KAT) berada dalam kisaran kontrol (Tabel 1) untuk semua fase vegetatif, pembungaan, dan pengisian biji. Sejalan dengan perkembangan tanaman, yaitu pada fase pembungaan dan pengisian biji, kondisi KAT ketiga genotip pada setiap pemberian air terus menurun, sekalipun masih berada dalam kisaran kontrol (Tabel 1), dan yang terendah berada pada perlakuan pemberian air 25\% KL.

Pada fase pembungaan untuk ketiga genotip dengan tingkat pemberian air 75, 50, dan 25\% KL, kondisi KAT semakin menjauh dari kontrol (Tabel 1) dan mendekati titik layu permanen, masingmasing dengan rata-rata penurunan kandungan air tanah pada fase pembungaan 21,50\% (75\% KL); 23,25\% (50\% KL), dan 25,91\% (25\% KL). Demikian pula yang terjadi pada fase pengisian biji untuk ketiga genotip dengan tingkat pemberian air yang sama, terjadi penurunan kandungan air tanah yang semakin berkurang dibandingkan kontrol (Tabel 1), dengan penurunan masing-masing $25,29 \%$ (75\% KL); 26,71\% (50\% KL), dan 29,50\% $(25 \% \mathrm{KL})$. Semua penurunan tersebut menyebabkan tanaman berada pada kondisi KAT mendekati titik layu permanen (Tabel 1). Umur berbunga ketiga genotip adalah 99 HST dan umur panen adalah 140 HST.

Tabel 1. Kisaran persentase kandungan air tanah (KAT) untuk setiap perlakuan pada fase vegetatif, pembungaan dan pengisian biji (\%).

\begin{tabular}{|c|c|c|c|c|}
\hline Perlakuan & \multicolumn{3}{|c|}{$\begin{array}{l}\text { Kisaran KAT pada } \mathrm{pF} 4,2 \text { dan } \mathrm{pF} 2,54(\%) \text { dalam setiap fase } \\
\text { pertumbuhan tanaman }\end{array}$} & \multirow{2}{*}{$\begin{array}{l}\text { Kisaran KAT pada } \\
\text { titik layu permanen }(\mathrm{pF} \\
4,2) \text { dan kapasitas } \\
\text { lapang }(\mathrm{pF} 2,54) \text { sebaga } \\
\left.\text { kontrol }(\%)^{*}\right)\end{array}$} \\
\hline $\begin{array}{l}\text { Genotip dan } \\
\text { Pemberian Air }\end{array}$ & $\begin{array}{l}\text { KAT Fase Vegetatif } \\
(\%) \text { (hari ke } 29-48)\end{array}$ & $\begin{array}{c}\text { KAT Fase } \\
\text { Pembungaan } \\
(\%)(\text { hari ke } 49-71)\end{array}$ & $\begin{array}{c}\text { KAT Fase } \\
\text { Pengisian Biji } \\
(\%)(\text { hari ke } 72-86)\end{array}$ & \\
\hline$\overline{\mathrm{g}_{1} \mathrm{k}_{1}(75 \% \mathrm{KL})}$ & $30,81-39,97$ & $30,08-37,81$ & $29,94-35,54$ & \\
\hline $\mathrm{g}_{2} \mathrm{k}_{1}(75 \% \mathrm{KL})$ & $31,18-40,65$ & $30,13-37,18$ & $29,96-36,07$ & \\
\hline $\mathrm{g}_{3} \mathrm{k}_{1}(75 \% \mathrm{KL})$ & $31,25-42,08$ & $30,53-38,60$ & $29,98-36,25$ & \\
\hline $\mathrm{g}_{1} \mathrm{k}_{2}(50 \% \mathrm{KL})$ & $29,70-37,79$ & $29,62-35,79$ & $29,52-34,68$ & $27,16-48,13$ \\
\hline $\mathrm{g}_{2} \mathrm{k}_{2}(50 \% \mathrm{KL})$ & $30,40-40,65$ & $29,93-37,08$ & $29,65-35,85$ & \\
\hline $\mathrm{g}_{3} \mathrm{k}_{2}(50 \% \mathrm{KL})$ & $30,55-41,12$ & $29,86-37,96$ & $29,70-35,28$ & \\
\hline $\mathrm{g}_{1} \mathrm{k}_{3}(25 \% \mathrm{KL})$ & $27,44-35,73$ & $27,30-34,91$ & $27,22-33,13$ & \\
\hline $\mathrm{g}_{2} \mathrm{k}_{3}(25 \% \mathrm{KL})$ & $28,65-38,11$ & $27,71-36,20$ & $27,42-35,18$ & \\
\hline $\mathrm{g}_{3} \mathrm{k}_{3}(25 \% \mathrm{KL})$ & $28,01-38,15$ & $27,76-35,88$ & $27,50-33,47$ & \\
\hline
\end{tabular}

Keterangan : $\mathrm{g}=$ genotip; $\mathrm{k}=$ pemberian air, $\mathrm{KL}=$ kapasitas lapang

*) kondisi kandungan air tanah sebelum ada tanaman 
Dihubungkan dengan kandungan prolin pada Tabel 2, perlakuan genotip $\mathrm{g}_{1}$ dengan tiga pemberian air yang berbeda $\left(k_{1}, k_{2}\right.$ dan $\left.k_{3}\right)$ menunjukkan kandungan prolin yang lebih tinggi dibandingkan dengan kedua genotip lainnya. Hal ini mengindikasikan bahwa genotip $\mathrm{g}_{1}$ merupakan genotip yang cenderung memiliki ketahanan lebih baik terhadap kondisi cekaman kekurangan air dibandingkan dua genotip lainnya.

Seperti diketahui bahwa kandungan prolin pada tanaman akan meningkat seiring dengan berkurangnya kandungan air tanah. Artinya kekurangan air sangat berpengaruh terhadap akumulasi prolin pada tanaman. Kenyataan ini sesuai dengan pernyataan Pireivatlou et al. (2010), bahwa kandungan prolin yang dihasilkan pada kondisi kekeringan jauh lebih tinggi jika dibandingkan dengan kondisi normal. Hal ini dimaksudkan untuk menjaga tekanan turgor. Sejalan dengan hasil penelitian Rahayu et al. (2016), bahwa tanaman padi gogo yang ditanam pada kondisi kandungan air tanah $50 \%$ kapasitas lapang menghasilkan prolin dengan kandungan yang lebih tinggi dibandingkan dengan yang ditanam pada kondisi kandungan air tanah 100\% kapasitas lapang.

Tabel 2. Pengaruh genotip dan pemberian air terhadap kandungan prolin.

\begin{tabular}{lccc}
\hline Genotip (G) & \multicolumn{3}{c}{ Kandungan Prolin pada pemberian } \\
& Air (K) (\%) $\left(\mathrm{mmol} \mathrm{g}^{-1}\right.$ berat basah) \\
\hline & $\mathrm{k}_{1}(75 \%$ & $\mathrm{k}_{2}(50 \%$ & $\mathrm{k}_{3}(25 \%$ \\
& $\mathrm{KL})$ & $\mathrm{KL})$ & $\mathrm{KL})$ \\
\hline g $_{1}$ (genotip 44) & 7,07 & 13,61 & 21,08 \\
$\mathrm{~g}_{2}$ (genotip 46) & 3,51 & 5,02 & 8,09 \\
$\mathrm{~g}_{3}$ (genotip 48) & 4,24 & 6,05 & 8,41 \\
\hline
\end{tabular}

Keterangan : $\mathrm{k}_{1}=75 \%$ kapasitas lapang, $\mathrm{k}_{2}=50 \%$ kapasitas lapang, $\mathrm{k}_{3}=25 \%$ kapasitas lapang

Kandungan air relatif pada daun (KARD) yang ditunjukkan oleh Tabel 3. Pada genotip $\mathrm{g}_{1}$, $\mathrm{g}_{2}$, dan $\mathrm{g}_{3}$, terjadi laju penurunan sejak fase vegetatif ke fase pembungaan dan fase pengisian biji pada setiap level pemberian air dibawah $50 \%$. Penurunan paling rendah terjadi pada level pemberian air 25\% KL.

Kandungan air relatif daun merupakan peubah ketahanan tanaman menghadapi cekaman kekeringan (Quilambo, 2004), karena menggambarkan status air dan tekanan turgor dari sel-sel daun, khususnya pada saat tanaman mengalami penurunan potensial air.
Tabel 3. Kandungan Air Relatif Daun (KARD) pada fase vegetatif, pembungaan, dan pengisian biji (\%).

\begin{tabular}{|c|c|c|c|c|}
\hline \multirow[t]{2}{*}{ Genotip } & \multirow{2}{*}{$\begin{array}{c}\text { Pemberian } \\
\text { Air }\end{array}$} & $\begin{array}{c}\text { KARD } \\
\text { fase } \\
\text { vegetatif }\end{array}$ & $\begin{array}{l}\text { KARD } \\
\text { fase } \\
\text { pembun } \\
\text { gaan }\end{array}$ & $\begin{array}{c}\text { KARD } \\
\text { fase } \\
\text { pengisia } \\
\text { n biji }\end{array}$ \\
\hline & & $\begin{array}{c}\text { hari ke } \\
(29-43) \\
\%\end{array}$ & $\begin{array}{c}\text { hari ke } \\
(44-71) \\
\%\end{array}$ & $\begin{array}{c}\text { hari ke } \\
(72-86) \\
\%\end{array}$ \\
\hline \multirow[t]{3}{*}{$\mathrm{g}_{1}$} & $\mathrm{k}_{1}(75 \% \mathrm{KL})$ & 75,00 & 53,50 & 34,72 \\
\hline & $\mathrm{k}_{2}(50 \% \mathrm{KL})$ & 72,09 & 38,92 & 29,67 \\
\hline & $\mathrm{k}_{3}(25 \% \mathrm{KL})$ & 34,78 & 31,14 & 27,34 \\
\hline \multirow[t]{3}{*}{$\overline{g_{2}}$} & $\mathrm{k}_{1}(75 \% \mathrm{KL})$ & 77,14 & 49,50 & 44,29 \\
\hline & $\mathrm{k}_{2}(50 \% \mathrm{KL})$ & 70,45 & 42,14 & 28,57 \\
\hline & $\mathrm{k}_{3}(25 \% \mathrm{KL})$ & 65,95 & 39,08 & 27,41 \\
\hline \multirow[t]{3}{*}{$g_{3}$} & $\mathrm{k}_{1}(75 \% \mathrm{KL})$ & 73,68 & 44,42 & 42,26 \\
\hline & $\mathrm{k}_{2}(50 \% \mathrm{KL})$ & 69,44 & 44,15 & 27,10 \\
\hline & $\mathrm{k}_{3}(25 \% \mathrm{KL})$ & 65,95 & 36,66 & 22,66 \\
\hline
\end{tabular}

Cekaman kekeringan menyebabkan turunnya tekanan turgor, sehingga stomata menutup. Penurunan KARD akan menurunkan konduktan stomata daun dan secara perlahan akan menurunkan konsentrasi $\mathrm{CO}_{2}$ di dalam daun sehingga dapat menurunkan laju fotosintesis (Lakitan, 2013). Penurunan kandungan air daun pada tiap genotip dengan perlakuan pemberian air yang semakin berkurang (75, 50 dan $25 \% \mathrm{KL})$,disebabkan oleh laju transpirasi yang jauh lebih besar dari pada laju penyerapan air oleh akar. Selanjutnya yang terjadi pada jumlah anakan per rumpun 77 HST, indeks klorofil daun, dan NPA, terlihat jelas bahwa genotip $\mathrm{g}_{1}$ menunjukkan nilai yang lebih rendah dibandingkan genotip $\mathrm{g}_{2}$ dan $\mathrm{g}_{3}$ (Tabel 4). Hal ini mengindikasikan bahwa genotip $\mathrm{g}_{1}$ memiliki hasil yang lebih rendah dibandingkan kedua genotip lainnya.

Pada pemberian air $\mathrm{k}_{3}(25 \% \mathrm{KL})$, jumlah anakan pada tiap genotip sangat rendah. Hal ini disebabkan KAT pada $\mathrm{k}_{3}$ untuk ketiga genotip pada fase tersebut mengalami penurunan sebesar kurang lebih 25\% dari kapasitas lapang dan kondisinya mendekati titik layu permanen (Tabel 1). Proses pembentukan anakan sangat dipengaruhi oleh adanya ketersediaan air yang cukup, yang berdampak pada jumlah anakan. Air yang cukup dapat melarutkan unsur hara yang dibutuhkan tanaman untuk membentuk anakan dan membuat turgiditas sel menjadi tinggi, sehingga pembelahan sel dapat terjadi. Selain itu, faktor genetik juga sangat mempengaruhi jumlah anakan. Menurut data 
deskripsi jawawut diketahui bahwa genotip $\mathrm{g}_{1}$ (genotip 44) memiliki jumlah anakan 8,67 sedangkan genotip $g_{2}$ (genotip 46) dan $g_{3}$ (genotip 48) memiliki jumlah anakan 13,40 dan 13,80 (Miswarti et al., 2014). Hasil Penelitian Brunda et al. (2015) terjadi penurunan jumlah anakan seiring meningkatnya intensitas cekaman kekeringan. Penurunan jumlah anakan secara nyata terjadi mulai pada kandungan lengas tanah $50 \%$ kapasitas lapang.

Perlakuan genotip $g_{1}, g_{2}, g_{3}$ memberikan perbedaan nyata pada indeks klorofil daun. Masing-masing genotip jawawut memiliki karakter yang berbeda berdasarkan sifat genotipnya. Kandungan klorofil yang tinggi akan berpengaruh terhadap besarnya hasil fotosintesis yang terjadi dan memiliki pengaruh positif terhadap hasil panen tanaman.

Tabel 4. Pengaruh genotip dan pemberian air terhadap jumlah anakan per rumpun, Indeks Klorofil Daun, dan Nisbah Pupus Akar (NPA).

\begin{tabular}{|c|c|c|c|}
\hline $\begin{array}{l}\text { Perlakuan } \\
\text { Genotip }(\mathrm{G}) \\
\text { dan Pemberian } \\
\text { air }(\mathrm{k})\end{array}$ & $\begin{array}{l}\text { Jumlah } \\
\text { anakan per } \\
\text { rumpun } \\
70 \text { hst } \\
\text { (batang) }\end{array}$ & $\begin{array}{l}\text { Indeks } \\
\text { klorofil } \\
\text { daun }\end{array}$ & NPA \\
\hline \multicolumn{4}{|l|}{ Genotip (G) } \\
\hline $\mathrm{g}_{1}$ (genotip 44) & $7,11 \mathrm{a}$ & $7,31 \mathrm{a}$ & $2,93 \mathrm{a}$ \\
\hline $\mathrm{g}_{2}$ (genotip 46) & $8,74 \mathrm{ab}$ & $7,66 \mathrm{~b}$ & $4,18 \mathrm{~b}$ \\
\hline $\mathrm{g}_{3}$ (genotip 48) & $10,26 \mathrm{~b}$ & $7,66 \mathrm{~b}$ & $4,32 \mathrm{~b}$ \\
\hline \multicolumn{4}{|l|}{ Pemberian air (K) } \\
\hline $\mathrm{k}_{1}(75 \%) \mathrm{KL}$ & $10,00 \mathrm{~b}$ & $7,64 \mathrm{~b}$ & $4,09 \mathrm{~b}$ \\
\hline $\mathrm{k}_{2}(50 \%) \mathrm{KL}$ & $8,41 \mathrm{ab}$ & $7,51 \mathrm{~b}$ & $3,76 \mathrm{a}$ \\
\hline $\mathrm{k}_{3}(25 \%) \mathrm{KL}$ & $7,70 \mathrm{a}$ & $6,86 \mathrm{a}$ & $3,59 \mathrm{a}$ \\
\hline
\end{tabular}

Pengaruh perlakuan pemberian air, $\mathrm{k}_{1}(75 \%$ KL) dan $\mathrm{k}_{2}(50 \% \mathrm{KL})$ berbeda nyata dengan pemberian air $\mathrm{k}_{3}(25 \% \mathrm{KL})$. Hal ini disebabkan KAT pada $\mathrm{k}_{3}$ berada pada kisaran 27,44 - 38,15 $\%$ (Tabel 1) artinya KAT sudah berada di bawah kapasitas lapang dan mulai memasuki titik layu permanen pada fase vegetatif. Hal ini sejalan dengan pendapat Song dan Yunia (2011), bahwa respons tanaman terhadap kekurangan air pada umumnya ditunjukkan dengan penurunan kandungan klorofil daun. Penurunan kandungan klorofil pada saat tanaman kekurangan air berkaitan dengan akitivitas perangkat fotosintesis dan menurunkan laju fotosintesis tanaman. Kekurangan air akan mempengaruhi kandungan dan organisasi klorofil dalam kloroplas pada jaringan. Hasil penelitian Gomes et al. (2008) menunjukkan bahwa kekurangan air pada kelapa kerdil hijau Brazilia mengakibatkan penurunan konsentrasi klorofil daun tiap unit luas daun.

Berdasarkan pengaruh mandiri, NPA tertinggi dicapai oleh $\mathrm{k}_{1}(75 \% \mathrm{KL})$, berbeda nyata dengan $\mathrm{k}_{2}(50 \% \mathrm{KL})$ dan $\mathrm{k}_{3}(25 \% \mathrm{KL})$. Nisbah pupus akar pada genotip $\mathrm{g}_{1}$ lebih kecil nyata dibandingkan dengan kedua genotip lainnya ( $g_{2}$ dan $\left.g_{3}\right)$. Hal ini menunjukkan bahwa $\mathrm{g}_{2}$ dan $\mathrm{g}_{3}$ merupakan genotip yang memiliki potensi hasil lebih tinggi dibandingkan dengan $\mathrm{g}_{1}$, sehingga pertumbuhan dan perkembangan pupus akar berada dalam keadaan sepadan lebih besar. Palupi dan Dediwiryanto (2008) menyatakan besarnya NPA berkaitan dengan tanaman mengabsorbsi air untuk mempertahankan potensial air tetap tinggi pada saat tanaman mengalami kekurangan air. Selanjutnya penelitian Hanum et al. (2007) bahwa pada tanaman kedelai kekeringan menurunkan berat kering akar dan tajuk pada pemberian air $80 \%$ kapasitas lapang menjadi $40 \%$ kapasitas lapang.

Tabel 5. Nilai rata-rata pengaruh genotip jawawut dan kandungan air tanah terhadap konduktan stomata pada $49 \mathrm{HST}\left(\mathrm{mmol} \mathrm{m} \mathrm{m}^{-2} \mathrm{~s}^{-1}\right.$.

\begin{tabular}{|c|c|c|c|}
\hline \multirow{2}{*}{$\begin{array}{l}\text { Genotip } \\
\text { (G) }\end{array}$} & \multicolumn{3}{|c|}{ Pemberian Air (K) (\%) } \\
\hline & $\mathrm{k}_{1}(75 \% \mathrm{KL})$ & $\mathrm{k}_{2}(50 \% \mathrm{KL})$ & $\mathrm{k}_{3}(25 \% \mathrm{KL})$ \\
\hline $\mathrm{g}_{1}$ (genotip & 131,86 a & $125,93 \mathrm{~b}$ & $49,82 \mathrm{a}$ \\
\hline 44$)$ & B & B & A \\
\hline $\mathrm{g}_{2}$ (genotip & $136,28 \mathrm{a}$ & $116,26 b$ & 43,03 a \\
\hline 46) & B & B & A \\
\hline $\mathrm{g}_{3}$ (genotip & 118,03 a & $98,53 \mathrm{a}$ & $37,51 \mathrm{a}$ \\
\hline 48) & B & B & A \\
\hline
\end{tabular}

Keterangan: Nilai rata-rata yang ditandai huruf kecil yang sama (vertikal) dan huruf kapital yang sama (horizontal) tidak berbeda nyata menurut uji Duncan pada taraf $5 \%$.

Terdapat interaksi antara genotip dan pemberian air pada pengamatan jumlah konduktan stomata (Tabel 5). Konduktan stomata pada setiap genotip (genotip $\mathrm{g}_{1}, \mathrm{~g}_{2}$ dan $\mathrm{g}_{3}$ ) pada pemberian air $\mathrm{k}_{1}$ dan $\mathrm{k}_{2}(75 \%$ dan $50 \% \mathrm{KL})$ menghasilkan nilai konduktan stomata lebih tinggi dibandingkan pemberian air $\mathrm{k}_{3}(25 \% \mathrm{KL})$. Pemberian air $\mathrm{k}_{3}(25 \% \mathrm{KL})$ pada ketiga genotip menghasilkan nilai konduktan stomata lebih rendah disebabkan pada pemberian air $\mathrm{k}_{3}(25 \%$ KL) KAT berkisar 27,44 - 38,15\% artinya pada 
fase vegetatif KAT telah mendekati titik layu permanen dengan penurunan kandungan air tanah sebesar 22,44 \% (Tabel 1) sehingga tanaman mengalami kekurangan air yang cukup banyak. Respons pertama tanaman terhadap kondisi defisit air yang besar ialah dengan cara menutup stomata. Lakitan (2013) menyatakan bahwa tanaman harus mempertahankan potensial air dengan mekanisme penutupan stomata atau daun menggulung untuk pertumbuhannya. Pembukaan dan penutupan stomata ditentukan oleh tekanan turgor dari kedua sel penjaga, sementara itu tekanan turgor dipengaruhi oleh banyaknya air yang masuk ke sel penjaga. Penurunan konduktan stomata ini terjadi pada tumbuhan untuk mengurangi kehilangan air yang berlebihan akibat cekaman air yang terjadi. Hasil penelitian Anggraini et al. (2015) menyatakan bahwa konduktan stomata pada tanaman black locust (Robinia pseudoacacia) dengan kondisi kekeringan (30-40\% KL) tercatat lebih rendah dibandingkan dengan kondisi cukup air (70-80\% KL).

Tabel 6. Pengaruh genotip dan pemberian air terhadap bobot malai rumpun-1, bobot biji rumpun $^{-1}$, bobot 1000 butir.

\begin{tabular}{|c|c|c|c|}
\hline $\begin{array}{l}\text { Perlakuan Genotip } \\
\text { (G) dan } \\
\text { Pemberian air (K) }\end{array}$ & $\begin{array}{l}\text { Bobot } \\
\text { malai } \\
\text { rumpun-1 } \\
\qquad(\mathrm{g})\end{array}$ & $\begin{array}{l}\text { Bobot } \\
\text { biji } \\
\text { rumpun- } \\
{ }^{1}(\mathrm{~g})\end{array}$ & $\begin{array}{l}\text { Bobot } \\
1000 \\
\text { butir }(\mathrm{g})\end{array}$ \\
\hline \multicolumn{4}{|l|}{ Genotip (G) } \\
\hline $\mathrm{g}_{1}$ (genotip 44) & $43,80 \mathrm{a}$ & $25,81 \mathrm{a}$ & $1,28 \mathrm{a}$ \\
\hline $\mathrm{g}_{2}$ (genotip 46) & $45,59 \mathrm{a}$ & $32,50 \mathrm{~b}$ & $1,31 \mathrm{a}$ \\
\hline $\mathrm{g}_{3}$ (genotip 48) & $46,59 \mathrm{a}$ & $32,57 \mathrm{~b}$ & $1,39 \mathrm{a}$ \\
\hline \multicolumn{4}{|l|}{ Pemberian air (K) } \\
\hline $\mathrm{k}_{1}(75 \% \mathrm{KL})$ & $61,13 \mathrm{c}$ & $39,10 \mathrm{c}$ & $1,17 \mathrm{~b}$ \\
\hline $\mathrm{k}_{2}(50 \% \mathrm{KL})$ & $45,55 \mathrm{~b}$ & $33,89 \mathrm{~b}$ & $1,05 \mathrm{~b}$ \\
\hline $\mathrm{k}_{3}(25 \% \mathrm{KL})$ & 29,19 a & $17,89 \mathrm{a}$ & $0,60 \mathrm{a}$ \\
\hline
\end{tabular}

Keterangan : Angka yang ditandai dengan huruf berbeda menyatakan berbeda nyata menurut Uji Jarak Berganda Duncan pada taraf 5\%.

Berdasarkan Tabel 6 di atas terlihat bahwa perbedaan bobot malai rumpun ${ }^{-1}$ pada setiap genotip sangat kecil sehingga genotip $\mathrm{g}_{1}, \mathrm{~g}_{2}$, dan $\mathrm{g}_{3}$ memiliki bobot malai rumpun ${ }^{-1}$ yang hampir sama. Pada pemberian air $\mathrm{k}_{1}, \mathrm{k}_{2}$ dan $\mathrm{k}_{3}(75 \%$, $50 \%$, dan $25 \% \mathrm{KL}$ ) terlihat jelas perbedaan bobot malai masing-masing genotip. Pemberian air $\mathrm{k}_{3}$ (25\% KL) memiliki bobot malai paling rendah dibandingkan dengan pemberian air $\mathrm{k}_{1} \quad(75 \%$ KL) dan $\mathrm{k}_{2}(50 \% \mathrm{KL})$. Hal ini disebabkan KAT pada fase pengisian biji pada pemberian air $\mathrm{k}_{3}$ berada pada kisaran 27,22 - 35,18 \% (Tabel 1), artinya KAT sudah mendekati titik layu permanen. Matsuura et al. (2012) menyatakan bahwa dalam kondisi tanaman kekurangan air pada stadia generatif akan menyebabkan jumlah malai yang terbentuk akan berkurang. Perlakuan $75 \%$ kapasitas lapang $\left(\mathrm{k}_{1}\right)$ menghasilkan bobot malai lebih tinggi dibandingkan perlakuan $25 \%$ kapasitas lapang $\left(\mathrm{k}_{3}\right)$. Hasil penelitian yang sama terhadap bobot malai rumpun ${ }^{-1}$ oleh Brunda et al. (2015) menyatakan bobot malai rumpun ${ }^{-1}$ jawawut berkisar antara $23 \mathrm{~g}$ sampai $177 \mathrm{~g}$.

Pada bobot biji per rumpun, genotip $g_{1}$ memiliki bobot biji paling rendah dibandingkan dengan genotip $\mathrm{g}_{2}$ dan $\mathrm{g}_{3}$. Seperti diketahui bahwa masing-masing genotip jawawut memiliki karakter yang berbeda berdasarkan sifat genotipnya. Pemberian air $\mathrm{k}_{3}(25 \% \mathrm{KL})$ menghasilkan bobot biji per rumpun paling rendah dibandingkan dengan pemberian air $\mathrm{k}_{1}$ dan $\mathrm{k}_{2}$. Hal ini disebabkan karena KAT pada fase pengisian biji pada pemberian air $\mathrm{k}_{3}(25 \%$ KL) berada pada kisaran 27,22 - 35,18 \% (Tabel 1). Hal yang sama terjadi pada bobot malai per rumpun. Kadar air tanah bila sudah mulai memasuki titik layu permanen akan menghasilkan bobot biji per rumpun paling rendah. Proses pengisian biji dan translokasi fotosintat sangat sensitif terhadap cekaman air, yang berdampak terhadap pengurangan bobot biji tanaman. Penurunan hasil panen akibat adanya cekaman kekeringan juga telah dibuktikan oleh hasil penelitian yang dilakukan pada tanaman kedelai (Purwanto dan Agustono, 2010).

Genotip $g_{1}$ memiliki bobot 1000 butir paling rendah dibandingkan dengan genotip $\mathrm{g}_{2}$ dan $g_{3}$. Masing-masing genotip jawawut memiliki karakter yang berbeda berdasarkan sifat genotipnya. Selanjutnya pemberian air $\mathrm{k}_{1}$ (75\% KL) dan $\mathrm{k}_{2}(50 \% \mathrm{KL})$ memiliki bobot 1000 butir paling banyak dibandingkan dengan $\mathrm{k}_{3}$ (25\% KL). Pemberian air $\mathrm{k}_{3}(25 \%$ KL) pada ketiga genotip memiliki bobot 1000 butir paling rendah. Hal ini disebabkan pada fase pengisian biji, KAT pada pemberian air $\mathrm{k}_{3}$ berada pada kisaran yang sama dengan bobot malai dan bobot biji per rumpun, artinya KAT hampir memasuki titik layu permanen. Matsuura et al. (2012), mengatakan bahwa perbedaan bobot 1000 butir biji antara genotip dikarenakan adanya perbedaan pengisian biji karena pasokan asimilat ke biji oleh kondisi kekuatan sink dan source yang berbeda-beda. Hal ini dapat terjadi karena source/sumber fotosintat tanaman yang 
mendapat cekaman akan lebih sedikit dibandingkan dengan yang tidak mendapat cekaman. Hasil penelitian Evita (2012) menunjukkan bahwa pemberian air pada kondisi 50\% dan $25 \%$ KL bobot 100 biji kacang tanah lebih rendah dibandingkan dengan bobot 100 biji pada pemberian air kondisi 75\% KL. Perbedaan hasil ini disebabkan tanaman kekurangan air pada masa pertumbuhan vegetatif maupun perkembangan generatif seperti pembentukan bunga dan pengisian polong.

Kurva respons yang menunjukkan bentuk hubungan antara hasil biji per rumpun dengan beberapa variabel, ditunjukkan pada Gambar 1 di bawah ini.

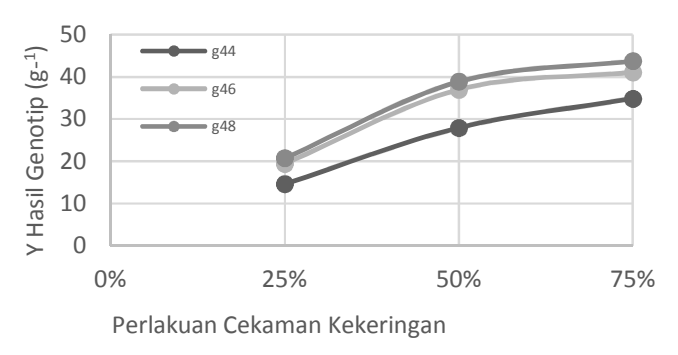

Gambar 1. Kurva respons hubungan antara tiga genotip jawawut dengan perlakuan cekaman kekeringan.

Bentuk kurva untuk $\mathrm{g}_{2}(\mathrm{~g} 46)$ dan $\mathrm{g}_{3}(\mathrm{~g} 48)$ kuadratik, sedangkan $g_{1}$ (g44) linier, dengan hasil biji per rumpun maksimum pada pemberian air $75 \%$ KL untuk genotip $\mathrm{g}_{2}$ adalah 41,08 gram dan $\mathrm{g}_{3}$ 43, 78 gram, sedangkan untuk $\mathrm{g}_{1}$ menghasilkan 34,83 gram. Persamaan regresi masing-masing adalah:

$\mathrm{Yg}_{1}=87-0,103 \mathrm{X}_{1}^{*}+2,96 \mathrm{X}_{2}-57,8 \mathrm{X}_{3}-12,4 \mathrm{X}_{4}-$ $4,4 X_{5}{ }^{*}+0,95 X_{6}^{*}+9,36 X_{7}^{*}$.

$\mathrm{R}^{2}=95,0 \%$

$\mathrm{Yg}_{2}=-13,9+0,211 \mathrm{X}_{1}{ }^{*}+3,14 \mathrm{X}_{2}+3,1 \mathrm{X}_{3}{ }^{*}-1,03 \mathrm{X}_{4}$ $-2,95 X_{5}{ }^{*}+1,32 X_{6}{ }^{*}+1,58 X_{7}{ }^{*}$.

$\mathrm{R}^{2}=90,3 \%$

$\mathrm{Yg}_{3}=-24,4-0,0635 \mathrm{X}_{1}{ }^{*}-0,401 \mathrm{X}_{2}-2,85 \mathrm{X}_{3}{ }^{*}-$

$0,510 X_{4}+3,68 X_{5}{ }^{*}-0,046 X_{6}{ }^{*}+2,69 X_{7}{ }^{*}$.

$\mathrm{R}^{2}=99,9 \%$

Keterangan :

$\mathrm{Y}=$ hasil biji per rumpun ; $\mathrm{X}_{1}=$ tinggi tanaman, $\mathrm{X}_{2}=$ jumlah anakan, $\mathrm{X}_{3}=$ indeks luas daun, $\mathrm{X}_{4}=$ nisbah pupus akar, $X_{5}=$ Panjang malai, $X_{6}=$ bobot malai, $X_{7}=$ bobot 1000 butir.

Pada Tabel 7 ditunjukkan koreksi antara komponen pertumbuhan dan hasil terhadap bobot biji per rumpun pada ketiga genotip $g_{1}, g_{2}$, dan $g_{3}$ akibat perlakuan pemberian air.

Tabel 7. Korelasi antara bobot biji per rumpun dengan berbagai komponen.

\begin{tabular}{clllllll}
\hline \multirow{2}{*}{ Genotip } & \multicolumn{3}{l}{ Komponen } \\
\cline { 2 - 6 } & $X_{1} X_{2}$ & $X_{3}$ & $X_{4}$ & $X_{5}$ & $X_{6}$ & $X_{7}$ \\
\hline g $_{1}$ (genotip 44) & $0.890^{*} 0.564$ & 0.346 & 0.314 & $0.919^{*}$ & $0.743^{*}$ & $0.945^{*}$ \\
g $_{2}$ (genotip 46) & $0.889^{*} 0.517$ & $0.861^{*}$ & 0.304 & $0.797^{*}$ & $0.859^{*}$ & $0.966^{*}$ \\
g & (genotip 48) & $0.926^{*} 0.498$ & $0.748^{*}$ & 0.172 & $0.992^{*}$ & $0.765^{*}$ & $0.995^{*}$ \\
\hline Keterangan : Tanda bintang berbeda nyata
\end{tabular}

Tabel 8. Indeks sensitivitas cekaman kekeringan (S).

\begin{tabular}{|c|c|c|c|c|c|c|}
\hline \multirow[t]{2}{*}{ Peubah } & \multicolumn{6}{|c|}{ Genotip (G) } \\
\hline & g44 & Kriteria & g46 & Kriteria & $\mathrm{g} 48$ & Kriteria \\
\hline Tinggi tanaman 35 hst & 0.54 & MT & 1.27 & $\mathrm{P}$ & 1.25 & $\mathrm{P}$ \\
\hline Tinggi tanaman 42 hst & 1.16 & $\mathrm{P}$ & -0.93 & $\mathrm{~T}$ & 2.79 & $\mathrm{P}$ \\
\hline Tinggi tanaman 56 hst & 1.18 & $\mathrm{P}$ & 0.71 & MT & 1.04 & $\mathrm{P}$ \\
\hline Tinggi tanaman 70 hst & 1.01 & $\mathrm{P}$ & 1.04 & $\mathrm{P}$ & 0.94 & MT \\
\hline Jumlah anakan & 0.94 & MT & 0.95 & MT & 1.08 & $\mathrm{P}$ \\
\hline Indeks Klorofil Daun & 0.69 & MT & 1.43 & $\mathrm{P}$ & 0.85 & MT \\
\hline Indeks luas daun & -0.59 & $\mathrm{~T}$ & 1.51 & $\mathrm{P}$ & 1.70 & $\mathrm{P}$ \\
\hline Nisbah pupus akar & 1.51 & $\mathrm{P}$ & -0.21 & $\mathrm{~T}$ & 1.72 & $\mathrm{P}$ \\
\hline Konduktan Stomata & 0.94 & MT & 1.03 & $\mathrm{P}$ & 1.03 & $\mathrm{P}$ \\
\hline Panjang malai & 0.66 & MT & 1.22 & $\mathrm{P}$ & 1.03 & $\mathrm{P}$ \\
\hline Bobot malai & 1.03 & $\mathrm{P}$ & 0.95 & MT & 1.01 & $\mathrm{P}$ \\
\hline Bobot biji per rumpun & 1.07 & $\mathrm{P}$ & 0.97 & MT & 0.97 & MT \\
\hline Bobot 1000 butir & 1.13 & $\mathrm{P}$ & 0.97 & MT & 0.89 & MT \\
\hline Indeks panen & 0.92 & MT & 0.96 & MT & 1.17 & $\mathrm{P}$ \\
\hline
\end{tabular}

Keterangan: $\mathrm{T}=$ toleran jika nilai $\mathrm{S} \leq 0,5 ; \mathrm{MT}=$ medium toleran jika $0,5<\mathrm{S} \leq 1,0 ; \mathrm{P}=$ peka jika $\mathrm{S}>1,0$. 
Perhitungan indeks sensitivitas terhadap cekaman kekeringan digunakan untuk mendapatkan tingkat toleransi genotip tanaman (Tabel 8). Dari 14 variabel pengamatan, dihasilkan untuk $g_{1}$ (genotip 44) dengan 7 variabel peka, 6 medium toleran, dan satu toleran. Untuk $\mathrm{g}_{2}$ (genotip 46) memiliki 6 variabel peka, 6 medium toleran, dan 2 toleran, sedangkan g3 (genotip 48) memiliki 10 variabel peka, 4 medium toleran. Dari kenyataan tersebut dapat disimpulkan bahwa genotip $\mathrm{g}_{1}$ (genotip 44) dan $g_{2}$ (genotip 46) termasuk medium toleran, sedangkan genotip $g_{3}$ (genotip 48) termasuk peka.

Bila dihubungkan dengan kurva respons hasil biji per rumpun (Gambar 1), genotip 44 yang masih linier, menunjukkan bahwa genotip tersebut memiliki potensi toleransi lebih baik dibandingkan kedua genotip lainnya ( $g_{46}$ dan $\mathrm{g}_{48}$ ). Demikian pula hal ini, dapat ditelusuri dalam hal kemampuannya memproduksi prolin pada setiap level peberian air, dan produksi prolin terbanyak dihasilkan pada pemberian air terendah $25 \% \mathrm{KL}$, dibandingkan $\mathrm{g}_{2}$ dan $\mathrm{g}_{3}$ (Tabel 2) sebesar 21,08 vs 8,09 dan $8,41 \mathrm{mmol} \mathrm{g}^{-1}$ bobot basah.

\section{Kesimpulan}

1. Terdapat interaksi pada parameter konduktan stomata. Genotip 46 dan genotip 48 menghasilkan bobot biji per rumpun lebih banyak dibandingkan genotip 44, masingmasing sebesar 32,50 gram dan 32,57 gram vs 25,81 gram, namun genotip 48 merupakan genotip dengan kriteria peka $(\mathrm{P})$, memiliki indeks sensitivitas 1,25.

2. Genotip 44 dan genotip 46 termasuk kriteria medium toleran (MT) dengan indeks sensitivitas masing-masing 0,87 dan 0,85.

3. Genotip 44 sekalipun hasilnya paling rendah, namun memiliki potensi adaptif untuk dikembangkan di lahan kering dengan kemampuan menghasilkan prolin yang lebih banyak, dibandingkan genotip 46 dan 48 pada setiap level pemberian air 75\% KL, 50\% KL, dan 25\% KL, yaitu 7,07, 13,61, dan 21,08 mmol g-1 bobot basah, dengan respons hasil yang masih linier bila dikaitkan antara prolin, hasil dan indeks sensitivitas.

\section{Daftar Pustaka}

Anggraini, N., Faridah, E, dan Indrioko, S. (2015). Pengaruh cekaman kekeringan terhadap perilaku fisiologis dan pertumbuhan bibit black locust (Robinia pseudoacacia). Jurnal Ilmu Kehutanan. 9(1), 40-56.

Badan Pusat Statistik. (2016). Produksi padi, jagung, dan kedelai. Statistic 50/07/Th XVII 1 Juli 2016.

Brunda, S. M., Kamatar, M.Y., Naveenkumar, K.L., Ramling Hundekar, and Sowmya, H.M. (2015). Evaluation of foxtail millet (Setaria italic) genotype for grain yield and biophysical traits. Journal of Global Biosciences, 4(5), 2142-2149.

Evita. (2012). Pertumbuhan dan hasil kacang tanah (Archis hypogea L.) pada perbedaan tingkatan kandungan air. Jurnal Agron, 1(1), 26-32.

Gomes, F.B., Olivia, M.A., Nielke, M.S., de Almeida, A.F., Leite, H.G. L., and Aquine, L.A. (2008). Photosynthetic limitations in leaves of young brazilian green dwarf coconut (Cocos nucifera L. 'nana') palm under wellwatered conditions and recovering from drought stress. Journal Environmental and Experimental Botany , 6(2), 195-204.

Hanum, C., Mugnisjah Q., W.,Yahya, S., Sopandy, D., Idris, K, dan Sahar, A. (2007). Pertumbuhan akar kedelai pada cekaman aluminium kekeringan dan cekaman ganda aluminium dan kekeringan. Jurnal Agritrop. 26(1), 13-18.

Lakitan, B. (2013). Dasar-dasar fisiologi tumbuhan. Jakarta : Rajawali Press.

Matsuura, A., Tsuji, W., Inanaga, S., Murata, K. (2012). Effect of pre-and postheading water defisit on growth and grain yield of four millet. Journal Plant Prod Sci, 15(4), 323-331.

Miswarti., Nurmala, T, dan Anas. (2014). Karakterisasi dan kekerabatan 42 aksesi tanaman jawawut (Setaria italica L. Beauv). Litbang Pertanian Bengkulu.

Palupi, E.T, dan Dedwiryanto, Y. (2008). Kajian karakter ketahanan terhadap cekaman kekeringan pada beberapa genotipe bibit kelapa sawit (Elaeis guineensis Jacq.) Jurnal Agron, 36(1), 24-32.

Pireivatlou, M.J., Qasimov, N., Maralian, H. (2010). Effect of soil water stress on yield 
and proline content of four wheat lines. African Journal of Biotechnology, 9, 36-40.

Purwanto, dan Agustono, T. (2010). Kajian fisiologi tanaman kedelai pada berbagai kepadatan gulma teki dalam kondisi cekaman kekeringan. Jurnal Agroland, 17 (2), 85-90.

Quilambo, Q.A. (2004). Proline content, water retention capability and cell membrane integrity as parameters for drought tolerance in two peanut cultivars. South African Journal Of Botany, 70:227-234.

Rahayu, A.Y., Haryanto, T.A.D., dan Iftitah S.N. (2016). Pertumbuhan dan hasil padi gogo hubungannya dengan kandungan prolin dan 2-acetyl-1-pyrroline pada kondisi kadar air tanah berbeda. Jurnal Kultivasi, 15(3).
Rauf, A.W, dan Lestari, M.S. (2009). Pemanfaatan Komoditas Pangan Lokal sebagai Sumber Pangan Alternatif di Papua. Jurnal Litbang Pertanian, 28(2), 54-62.

Song, N, dan Yunia, B. (2011). Konsentrasi klorofil daun sebagai indikator kekurangan air pada tanaman. Jurnal Ilmiah Sains, 11(2), 169-170.

Widiatmoko, T., Agustono, T., dan Imania, M. (2012). Pertumbuhan dan hasil beberapa genotip kedelai berbiji besar pada cekaman kekeringan diberbagai stadia pertumbuhan. Jurnal Agrin, 16(1).

Yuwariah, Y., Sheli Mustikasari Dewi, Warid Ali Qosim, dan Anne Nuraini. 2019. Respons fisiologis pertumbuhan dan hasil tiga genotip jawawut terhadap cekaman kekeringan. Journal Agro, 6(1). 